\title{
Role of Gender in the Quality of Life and Functional Status in Stroke Patients with Urinary Incontinence
}

\author{
• B Başak Bilir Kaya, (1) Selin Süslü
}

Department of Physical Medicine and Rehabilitation, İstanbul Erenköy Physical Therapy and Rehabilitation Hospital, İstanbul, Turkey

Submitted: 06.09.2018 Accepted: 03.01.2019

Correspondence: Başak Bilir Kaya, Erenköy Fizik Tedavi ve Rehabilitasyon Hastanesi, Erenköy, İstanbul, Turkey

E-mail: basakbilir@gmail.com

asting

Keywords: Barthel Index; gender; incontinence; SF-36; stroke.

\begin{abstract}
Objective: This study aimed to evaluate the role of gender in the impact of urinary continence (UI) on the quality of life and physical functioning in stroke patients with UI.

Methods: This study included 128 stroke patients (64 male, 64 female) with UI and was conducted in the inpatient and outpatient clinics of a public rehabilitation hospital in June,July, and August 2018. Patients were asked to fill a structured questionnaire for colllection of demographic data and incontinence properties, SF-36 for evaluation of quality of life, and Barthel Index for evaluation of functional capacity.
\end{abstract}

Results: Mean ages of the male and female patients included in the study were $62 \pm 15.33$ and $58.77 \pm 16.10$ years, respectively. There was no statistically significant difference between genders for UI frequency, urine quantity, materials used for UI, and application to an healthcare institute for UI ( $>0.05)$. Use of sanitary pads for UI was associated with decreased quality of life $(p<0.05)$. There was a statistically significant difference between UI frequency and the "Physical Health" and "Mental Health" subdimension scores of SF-36 $(p<0.05)$.

Conclusion: Independent of gender, UI negatively affects the quality of life and social, work, and family life in stroke patients.

\section{INTRODUCTION}

After cardiovascular disease and malignancy, stroke is the third cause of death in developed countries. It is of great importance in terms of public health as it is associated with a high mortality risk. ${ }^{[1,2]}$ Post-stroke urinary incontinence (UI) and other urinary problems are common. ${ }^{[3]} \mathrm{UI}$ has been defined as "involuntary loss of urine that may cause a social and hygienic problem" by the International Continence Society (ICS). ${ }^{[4]}$

Although $\mathrm{Ul}$ is not a vital issue, it significantly decreases an individual's quality of life due to wetness and irritation. In addition, problems caused by UI may prevent the individual from fulfilling his/her physical functions. An individual with $\mathrm{UI}$ may face difficulty in maintaining daily living activities, such as feeding, bathing, dressing, and moving, and may ultimately become more dependent on his/her environment. $^{[5-10]}$

When the incontinence complaint period in females is prolonged, incidence rates of various emotional disorders, such as shame, social isolation, anxiety, deterioration in body image, depression, and guilt, are reportedly increased more than in males, and this situation adversely affects the quality of life and physical function of the individual. ${ }^{[1-13]}$
Our research study was planned to determine the role of gender in the impact of UI on the quality of life and physical function in stroke patients.

\section{MATERIAL AND METHODS}

This study was performed prospectively in 128 patients (64 male, 64 female) who had been admitted to a public rehabilitation hospital between June 2018 and August 2018 and had been diagnosed with UI. No randomization technique was used and local ethics committee approval was obtained. After the demographic characteristics of the patients were recorded, SF-36, ${ }^{[14,15]}$ Barthel Index ${ }^{[16,17]}$ for functional status, and structured questionnaire were used to evaluate the clinical characteristics of the patients. The structured questionnaire was prepared in accordance with literature, and in addition to socio-demographic data, such as age, gender, marital status, and economic status, there were 33 questions to measure clinical characteristics of the disease, such as risk factors for UI, general health perception, health control information, and current chronic diseases (Appendix-I). Mentally healthy patients aged $>18$ years with the diagnosis of stroke and $U I$ were included in the study. 


\section{Statistical analysis}

For statistical analysis, percent distributions, Student's t-test, Pearson chi-square test, Mann-Whitney $U$ test, and multiple linear analysis were performed using NCSS (Number Cruncher Statistical System) 2007 statistical sotware (NCSS LLC, Kaysville, Utah, USA) program. $\mathrm{p}<0.05$ was evaluated as significant.

\section{RESULTS}

Gender-specific descriptive characteristics of 128 patients (64 male, 64 female) are presented in Table I.

When UI was evaluated based on gender, more than half of the patients $(50.8 \%)$ were found to have incontinence requiring continuous diaper use.

Regarding the relationship between Barthel Index and SF-36 subscale scores, the "Physical Health" and "Mental Health" subdimension scores of SF-36 were significantly correlated with the Barthel Index scores. The relevant details are presented in Table 3.

There was no statistically significant difference related to gender in the Barthel Index scores of the patients (Table 4).

When SF-36 subscale analysis was performed based on gender, no statistically significant difference was found (Table 5).

Regarding UI frequency, no statistically significant differences were found between the patient's age and educational status and the number of births in female patients $(p>0.05)$.

Regarding the distribution of pregnancies and births in female patients, no statistically significant relationship be- tween the number of vaginal deliveries and $U I$ incidence in females who participated in the study $(p>0.05)$ was found. Based on the educational status and the number of births in female patients, no statistically significant difference between the "Physical Health" and "Mental Health" subdimension scores of SF-36 was detected ( $p>0.05)$.

Based on the demographic characteristics of the patients and SF-36 scores, no statistically significant relationship between the age of the patients and the "Physical Health" subdimension scores of SF-36 was found ( $p>0.05)$, whereas a significantly negative relationship (mental health scores decreased with increasing age) was found between the demographic characteristics and the "Mental Health" subdimension scores $(p<0.05)$.

According to the results of the Post-Pock test performed to determine the difference, "Physical Health" and "Mental Health" subdimension scores of the patients who experienced monthly UI were significantly higher than those with a Ul frequency of $\geq 2$ times per month $(p<0.0 \mathrm{I})$.

There was a statistically significant difference between the scores obtained from the "Physical Health" and "Mental Health" subdimension scores of SF-36 according to the amount of urine loss during incontinence $(p<0.0 \mathrm{I})$. According to the results of the Post-Pock test, "Physical Health" and "Mental Health" subdimension scores of patients with a mild amount of involuntary urine loss were found to be significantly higher than in those with severe incontinence $(p<0.01)$.

Based on the methods used in case of incontinence, there was a statistically significant difference between the "Physical Health" and "Mental Health" subdimension scores of the patients $(p<0.05)$. According to the results of the PostPock tests to determine the differences between "Physi-

Table I. Distribution of descriptive characteristics according to the patients' gender

\begin{tabular}{|c|c|c|c|c|c|}
\hline & & \multicolumn{2}{|c|}{ Gender } & \multirow[t]{2}{*}{ Total } & \multirow[t]{2}{*}{$\mathbf{p}$} \\
\hline & & Female & Male & & \\
\hline \multirow[t]{2}{*}{ Age } & Mean \pm SD & $62.98 \pm 15.33$ & $58.77 \pm 16.10$ & $60.88 \pm 15.80$ & ${ }^{\mathrm{a}} 0.132$ \\
\hline & Minimum-maximum (median) & $20-85(63)$ & $20-88(62)$ & $20-88(63)$ & \\
\hline \multirow[t]{4}{*}{ Marital status } & Married & $37(57.8)$ & $45(70.3)$ & $82(64.1)$ & ${ }^{\circ} 0.020^{*}$ \\
\hline & Single & $4(6.3)$ & $10(15.6)$ & $14(10.9)$ & \\
\hline & Widowed & $20(31.3)$ & $8(12.5)$ & $28(21.9)$ & \\
\hline & Divorced/separate & $3(4.7)$ & I (I.6) & $4(3.1)$ & \\
\hline \multirow[t]{4}{*}{ Education } & Illiterate & $22(34.4)$ & $12(18.8)$ & $34(26.6)$ & ${ }^{c} 0.200$ \\
\hline & Primary & $27(42.2)$ & $30(46.9)$ & $57(44.5)$ & \\
\hline & Secondary-lycée & $12(18.8)$ & $16(25)$ & $28(21.9)$ & \\
\hline & University and above & $3(4.7)$ & $6(9.4)$ & $9(7)$ & \\
\hline \multirow[t]{5}{*}{ Work occupation } & Unemployed & $25(39.1)$ & $6(9.4)$ & $31(24.2)$ & ${ }^{c} 0.001^{* *}$ \\
\hline & Worker & I (I.6) & $4(6.3)$ & $5(3.9)$ & \\
\hline & Civil servant & $2(3.1)$ & I (I.6) & $3(2.3)$ & \\
\hline & Self-employed & $16(25)$ & $18(28.1)$ & $34(26.6)$ & \\
\hline & Retired & $20(31.3)$ & $35(54.7)$ & $55(43)$ & \\
\hline
\end{tabular}


Table 2. Distribution of urinary incontinence and related characteristics

\begin{tabular}{|c|c|c|c|c|}
\hline & \multicolumn{2}{|c|}{ Gender } & \multirow[t]{2}{*}{ Total } & \multirow[t]{2}{*}{$\mathbf{p}$} \\
\hline & Female & Male & & \\
\hline Frequency of urinary incontinence & $10(15.6)$ & II (I7.2) & $21(16.4)$ & ${ }^{\mathrm{a}} 0.666$ \\
\hline Once a month $\geq 2$ times a month & $19(29.7)$ & $23(35.9)$ & $42(32.8)$ & \\
\hline Requiring continuous use of diapers & $35(54.7)$ & $30(46.9)$ & $65(50.8)$ & \\
\hline \multicolumn{5}{|l|}{ Volume of urine leakage } \\
\hline Small & $15(23.4)$ & $18(28.1)$ & $33(25.8)$ & ${ }^{\mathrm{a}} 0.60 \mathrm{I}$ \\
\hline Moderate & $21(32.8)$ & $16(25)$ & $37(28.9)$ & \\
\hline Serious & $28(43.8)$ & $30(46.9)$ & $58(45.3)$ & \\
\hline \multicolumn{5}{|l|}{ What is done in case of urine leak? } \\
\hline Use of sanitary pads & $39(60.9)$ & $34(53.1)$ & $73(57.0)$ & ${ }^{\mathrm{a}} 0.456$ \\
\hline Change of underwear after each urine leak & II (I7.2) & $17(26.6)$ & $28(21.9)$ & \\
\hline Use of a urinary catheter & $6(9.4)$ & $8(12.5)$ & $14(10.9)$ & \\
\hline Use of towels/napkins & $8(12.5)$ & $5(7.8)$ & $13(10.2)$ & \\
\hline \multirow{2}{*}{\multicolumn{5}{|c|}{$\begin{array}{l}\text { Urinary Incontinence application to any healthcare } \\
\text { center due to incontinence }\end{array}$}} \\
\hline & & & & \\
\hline Yes & $35(54.7)$ & $37(57.8)$ & $72(56.3)$ & ${ }^{\mathrm{a}} 0.722$ \\
\hline No & $29(45.3)$ & $27(42.2)$ & $56(43.8)$ & \\
\hline
\end{tabular}

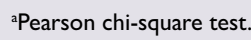

Table 3. Distribution of the relation between Barthel Index and SF-36 subscale scores

\begin{tabular}{lcc}
\hline & \multicolumn{2}{c}{ Barthel Index } \\
\cline { 2 - 3 } & $\mathbf{r}$ & $\mathbf{p}$ \\
\hline Physical health score & 0.423 & $0.001^{* *}$ \\
Physical function & 0.609 & $0.001^{* *}$ \\
Role difficulty & 0.245 & $0.005^{* *}$ \\
Pain & 0.250 & $0.004^{* *}$ \\
General health & 0.202 & $0.023^{*}$ \\
Mental health score & 0.264 & $0.003^{* *}$ \\
Vitality & 0.198 & $0.025^{*}$ \\
Social function & 0.300 & $0.001^{* *}$ \\
Emotional role difficulty & 0.145 & 0.103 \\
Mental health & -0.009 & 0.916 \\
\hline
\end{tabular}

$r=S$ pearman's correlation coefficient; ${ }^{*} p<0.05 ; * * p<0.01$.

cal Health" and "Mental Health" subdimension scores of patients using sanitary pads were found to be significantly lower than of those using towel napkins $(p<0.05)$.

\section{DISCUSSION}

Involuntary urine loss after stroke is an important symptom that can be seen at any age and affects the individual physically, socially, psychologically, and economically. ${ }^{[18,19]}$ In our study, UI incidence, the amount of urine loss, and materials used for urine loss were not significantly different between genders $(p>0.05)$ because there is no significant difference between age and education status of both groups. However, it can also be caused by the parallelism of the complications due to stroke.
Table 4. Evaluation of Barthel Index total score based on the patients' gender

\begin{tabular}{lccc}
\hline & \multicolumn{2}{c}{ Gender } & p \\
\cline { 2 - 3 } & $\begin{array}{c}\text { Female } \\
(\mathbf{n}=64)\end{array}$ & $\begin{array}{c}\text { Male } \\
(\mathbf{n}=64)\end{array}$ & \\
\hline Barthel & & & \\
$\quad$ Min-Max (Median) & $0-100(35)$ & $0-100(35)$ & ${ }^{2} 0.593$ \\
Mean \pm SD & $40.39 \pm 26.30$ & $39.38 \pm 31.38$ & \\
\hline
\end{tabular}

aMann-Whitney $U$ Test. No statistically significant difference was detected between genders for Barthel Index scores ( $p>0.05$ ). SD: Standard deviation.

In several studies on UI, mean age of patients with $\mathrm{UI}$ is generally $\geq 50$ years. ${ }^{[20,21]}$ In our study, mean ages of both genders (females, 62 \pm 15.33 years and males, 58.77 \pm 16.10 years) was compatible with the literature.

In our study, mild, moderate, and serious amounts of urine leakage were found in $25.8 \%, 28.9 \%$, and $45.3 \%$ of patients, respectively. In a previous study on patients without any neurological deficit related to stroke, Hannestad et al. ${ }^{[22]}$ detected mild, moderate, and severe UI in $24 \%, 31 \%$, and $44 \%$. of their female patients aged $\geq 60$ years. Bilgili et al. ${ }^{[5]}$ reported mild, moderate, and severe UI in $44 \%, 50.2 \%$, and $24.5 \%$ of their patients. In various studies, data on UI severity were not evaluated using the same scale and were given at wide intervals when defining the amount of urine loss. The large scale in data collection methods can be caused by the differences in the study areas and study data collection methods.

In their study on 229 patients, Kök et al. ${ }^{[23]}$ found that $41.17 \%$ of patients with UI used only sanitary pads, whereas $58.8 \%$ changed their underwears. In our study, 
Table 5. Evaluation of SF-36 subdimension Scores based on the patients' gender

\begin{tabular}{|c|c|c|c|c|}
\hline & & \multicolumn{2}{|c|}{ Gender } & \multirow[b]{2}{*}{$\mathbf{p}$} \\
\hline & & Female $(n=64)$ & Male $(n=64)$ & \\
\hline \multirow[t]{2}{*}{ Physical health score } & Min-Max (Median) & $7.5-79.25(30.38)$ & $10-85.5(33.25)$ & ${ }^{b} 0.168$ \\
\hline & Mean $\pm S D$ & $32.59 \pm 16.06$ & $37.28 \pm 18.52$ & \\
\hline \multirow[t]{2}{*}{ Physical function } & Min-Max (Median) & $0-80(2.5)$ & $0-100(10)$ & ${ }^{b} 0.151$ \\
\hline & Mean $\pm S D$ & $15.08 \pm 21.09$ & $19.06 \pm 22.99$ & \\
\hline \multirow[t]{2}{*}{ Role difficulty } & Min-Max (Median) & $0-100(0)$ & $0-100(0)$ & ${ }^{b} 0.078$ \\
\hline & Mean $\pm S D$ & $13.28 \pm 32.72$ & $22.27 \pm 38.35$ & \\
\hline \multirow[t]{2}{*}{ Pain } & Min-Max (Median) & $0-110(52)$ & $10-90(62)$ & ${ }^{\mathrm{a}} 0.081$ \\
\hline & Mean $\pm S D$ & $50.97 \pm 27.49$ & $58.81 \pm 22.76$ & \\
\hline \multirow[t]{2}{*}{ General health } & Min-Max (Median) & $12-87(50)$ & 5-92 (5I) & ${ }^{\mathrm{a}} 0.952$ \\
\hline & Mean $\pm S D$ & $50.73 \pm 15.86$ & $50.92 \pm 19.48$ & \\
\hline \multirow[t]{2}{*}{ Mental health score } & Min-Max (Median) & II-92.5 (38.75) & I0.88-92.75 (4I.38) & ${ }^{\mathrm{a}} 0.603$ \\
\hline & Mean $\pm S D$ & $43.43 \pm 18.53$ & $45.16 \pm 18.85$ & \\
\hline \multirow[t]{2}{*}{ Vitality } & Min-Max (Median) & $0-100(42.5)$ & $5-95(40)$ & ${ }^{\mathrm{a}} 0.593$ \\
\hline & Mean $\pm S D$ & $45.63 \pm 24.82$ & $43.44 \pm 21.23$ & \\
\hline \multirow[t]{2}{*}{ Social function } & Min-Max (Median) & $0-100(37.5)$ & $0-100(50)$ & ${ }^{\mathrm{b}} 0.147$ \\
\hline & Mean $\pm S D$ & $42.58 \pm 30.02$ & $50.98 \pm 32.53$ & \\
\hline \multirow[t]{2}{*}{ Emotional role difficulty } & Min-Max (Median) & $0-100(0)$ & $0-100(0)$ & ${ }^{b} 0.528$ \\
\hline & Mean $\pm S D$ & $21.35 \pm 39.11$ & $23.44 \pm 39.25$ & \\
\hline \multirow[t]{2}{*}{ Mental health } & Min-Max (Median) & $16-100(60)$ & $16-100(62)$ & ${ }^{\mathrm{a}} 0.507$ \\
\hline & Mean $\pm S D$ & $63.94 \pm 18.92$ & $61.81 \pm 17.19$ & \\
\hline
\end{tabular}

aStudent t-Test; 'Mann Whitney U Test. Patients' scores obtained from "Physical Health”, "Physical Function”, "Role Difficulty”, "Pain”, "General Health”, “Mental Health", "Vitality", "Social Function", and "Emotional role Difficulty", subdimensions of SF-36 did not demonstrate statistically significant differences between genders ( $p>0.05)$. SD: Standard deviation.

when the patients were verbally questioned about the reason underlying their use of a sanitary pad, it was found that more than half of the patients could not go to the toilet frequently because of their inability to move due to stroke.

In our study, no statistically significant difference was found between female and male patients in the frequency of applying to a healthcare institution due to UI. In a study, Lie et al. determined that female patients received less professional help than males, and this was associated with older age and low education status. ${ }^{[16]}$ In our study, no statistically significant difference was found between age and education status of female and male patients $(p>0.05)$. In addition, it was found that most patients $(51.8 \%)$ who did not apply to a healthcare institution due to UI perceived the symptoms to be mild. Many studies showing similarities with our study reported that most patients did not consider UI complaints to be a health issue. ${ }^{[9,24]}$

Based on patients' gender, there was no statistically significant difference between SF-36 and Barthel Index scores $(p>0.05)$. In our study, no difference was found between male and female patients, and this may be related to the lack of statistically significant differences between patients in terms of age, education status, and scores obtained. In addition, revelation of this fact shows that our study was conducted with an adequate sample size.

The number of births and delivery methods have been included as the etiologic factors of UI. ${ }^{[2]}$ Although not statis- tically significant $(p>0.05)$, Terzi et al. ${ }^{[25]}$ and Yilmaz et al. ${ }^{[26]}$ have found that UI prevalence was higher in females who had vaginal delivery than those who did not. These studies report that $\mathrm{UI}$ incidence increases due to the increase in the number of births, which causes atrophy of the nerves of the pelvic muscles. The conclusion of our study does not coincide with that of previous studies in literature because the patients with Ul did not have urge incontinence and had a problem with timely access to the toilet due to the damage of the centers that manage the urinary storage and voiding functions in the brain caused by stroke which is not related to the mode of delivery of the patients and the decrease in walking capacity of some patients.

In our study, it was found that quality of life of patients with IU was adversely affected as the patients aged. Many studies have reported that UI, a condition which worsens with advancing ag adversely affects the quality of life of the patients, decreases the patients' confidence, and causes a decrease in their social activities which isolates the patients from social life. ${ }^{[12,16,17]}$ In fact, Kelleher, ${ }^{[27]}$ Aylaz et al. ${ }^{[28]}$ reported that the quality of life of older females with $\mathrm{UI}$ is lower.

According to the educational status, there was no statistical difference between the SF-36 scores of the patients. As education status increases, quality of life scores increase in all cases. In previously conducted studies, the quality of life reportedly increases parallel to higher education status. ${ }^{[28,29]}$ 
Since $\mathrm{UI}$ is a social and a medical condition, it negatively affects the quality of life. ${ }^{[12,30]}$ In this study, the quality of life scores of the patients with UI were significantly higher than those requiring continuous diaper use $(p<0.05)$. In fact, Hunskaar and Visnes examined the quality of life of patients with $\mathrm{UI}$ and reported that quality of life was adversely affected by increased $\mathrm{Ul}$ incidence. ${ }^{[3]}$

In our study, the quality of life scores of the patients with small amounts of urine leakage were found to be significantly higher than those with serious UI $(p<0.0 I)$. In the study by Demir and Erbesler, a significantly negative correlation was found between the quality of life and amount of involuntary

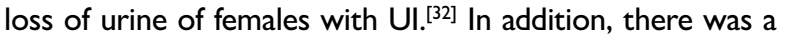
statistically significant difference between the use of sanitary pads and quality of life $(p<0.05)$. Parallel to our findings, Kocak et al., ${ }^{[33]}$ and Aslan et al. ${ }^{[34]}$ reported that patients with UI who used sanitary pads had a lower quality of life.

\section{Limitations}

In our study, no randomization technique was used for patient selection, and the reported amount of involuntary urine loss was not measured in milliliters using any measurement system, but was that as declared by the patients.

\section{CONCLUSION}

In this study, the role of gender in the impact of UI on the quality of life of stroke patients was investigated, and it was determined that, independent of gender, UI negatively affects the quality of life, and the physical, social, home, work, and family life of the patients.

Ethics Committee Approval

Approved by the local ethics committee (date: 09.05.2018, no: 73).

Peer-review

Internally peer-reviewed.

Authorship Contributions

Concept: B.B.K., S.S.; Design: B.B.K., S.S.; Data collection \&/or processing: B.B.K., S.S.; Analysis and/or interpretation: B.B.K., S.S.; Literature search: B.B.K., S.S.; Writing: B.B.K., S.S.; Critical review: B.B.K.

\section{Conflict of Interest}

None declared.

\section{REFERENCES}

1. Knutsen R, Knutsen SF, Curb JD, Reed DM, Kautz JA, Yano K. Predictive value of resting electrocardiograms for 12 year incidence of stroke in the honolulu heart program. Stroke 1988;19:555-9.

2. Gariballa SE, Hutchin TP, Sinclair AJ. Antioxidant capacity after acute ischaemic stroke. QJM 2002;9:685-90. [CrossRef]

3. Gündüz B, Özcan S. Nörojen mesane ve inme. Turkiye Klinikleri Journal of Physical Medicine Rehabilitation Special Topics 2016;9:84-8.

4. Agarwall BK, Agarwall N. Urinary incontinence: prevalence, risk factors, impact on quality of life and treatment seeking behaviour among middle aged women. Int Surg J 2017;4:1953-8. [CrossRef]
5. Bigili N, Akın B, Ege E, Ayaz S. Kadınlarda üriner inkontinans sıklığ1 ve etkileyen risk faktörleri. Turkiye Klinikleri J Med Sci 2008;2:488.

6. Park WH. Urinary incontinence and physician's attitude. J Korean Med Sci 2013;28:1559-60.

7. Küçükdeveci AA. Rehabilitasyonda yaşam kalitesi. Türk Fiz Tip Rehab Derg 2005;51:23-9.

8. Beji NK. Üriner inkontinans sorunu, epidemiyolojisi ve inkontinanslı hastanın tanı amacıyla değerlendirilmesi. İ.Ü.F.N.H.Y.O Hemşirelik Dergisi 2003;13:29-43.

9. Üstüner Top F, Saraç A, Yaşar G. Huzurevinde yaşayan bireylerde depresyon düzeyi, ölüm kaygısı ve günlük yaşam işlevlerinin belirlenmesi. Klinik Psikiyatri dergisi 2010;13:14-22. [CrossRef]

10. Soyuer F, Ünalan D, Öztürk A. İnme hastalarında yaş ve cinsiyetin fonksiyonel yetersizlik üzerine olan etkisi. İnönü Üniversitesi Tip Fakültesi Dergisi 2007;14:91-4.

11. $\ddot{O} z$ Ö, Altay B. Üriner İnkontinans Risk Faktörleri ve Hemşirelik Yaklaşımı İnönü Sağ Bil Derg 2017;6:34-7.

12. Li Y, Cai X, Glance LG, Mukamel DB. Gender differences in healthcare seeking behavior for urinary incontinence and the impact of socioeconomic status: a study of the medicare managed care population. Med Care 2007;45:1116-22. [CrossRef]

13. Özengin N, İnal B, Çankaya H, Bakar Y. Does the amount of urine leakage affect quality of life $\mathrm{n}$ women with stress urinary incontinence? A retrospective study. Anatol Clin 2017;22:107-13.

14. Ware JE, Sherborne CD. The MOS 36-itemshort form healty survey (SF-36). Medical Care 1992;30:473-83. [CrossRef]

15. Koçyiğit $\mathrm{H}$, Aydemir Ö, Ölmez N, Memiş A. Reliability and validity of the Turkish version of Short-form-36 (SF-36). İlaç ve Tedavi Dergisi 1999;12:102-6.

16. Mahoney FI, Barthel DW. Functional evaluation: The Barthel Index. Md State Med J 1965;14:61-5.

17. Küçükdeveci AA, Yavuzer G, Tennant A, Süldür N, Sonel B, Arasil T. Adaptation of the Modified Barthel Index for Use in Physical Medicine and Rehabilitation in Turkey. Scand J Rehabil Med 2000;32:87-92. [CrossRef]

18. Edwards DF, Hahn M, Dromerick A. Post stroke urinary loss, incontinence and life satisfaction: When does post stroke urinary loss become incontinence? Neuroul Urodyn 2006;25:39-45. [CrossRef]

19. Sayharman AA, Barçınlı G, Sayharman SE, Ünal O, Kuyumcuoğlu $\mathrm{U}$. The evaluation of success rates of stress urinary incontinence operations. Scie 2001;12:66-9.

20. Gelber DA, Good DC, Laven LJ, Verhulst SJ. Causes of urinary incontinence after acute hemispheric stroke. Stroke 1993;24:378-82.

21. Patel M, Coshall C, Rudd AG, Wolfe CD. Natural history and effects on 2 year outcomes of urinary incontinence after stroke. Stroke 2001;32:122-7. [CrossRef]

22. Hannestad YS, Rortveit G, Sandvik H, Hunskaar S; Norwegian EPINCONT study. Epidemiology of Incontinence in the County of Nord-Trøndelag. A community based epidemiological survey of female urinary incontinence: the Norwegian EPINCONT study. Epidemiology of Incontinence in the County of Nord-Trondelag. J Clin Epidemiol 2000;53:1150-7.

23. Kök G, Şenel N, Akyüz A. GATA jinekoloji polikliniğine başvuran 20 yaş üstü kadınların üriner inkontinans açısından farkındalık durumlarının değerlendirilmesi. Gülhane Tip Dergisi 2006;48:132-6.

24. Öztürk GZ, Toprak D, Basa E. 35 yaş üzeri kadınlarda üriner inkontinans sıklığı ve etkileyen faktörlerin değerlendirilmesi. Şişli Etfal Hastanesi Tip Bülteni 2012;46:172-3.

25. Terzi H, Terzi R, Kale A. 18 yaş üstü kadınlarda üriner inkontinans sıklığı ve etkileyen faktörler. Ege Tip Dergisi 2013;52:15-9.

26. Y1lmaz E, Muslu A, Özcan E. Üriner inkontinanslı kadınlarda yaşam kalitesi. Erciyes Üniversitesi Sağlık Bilimleri Fakültesi Dergisi 
2014;2:2.

27. Kelleher CJ. Quality of life. Urogynecology 1997;673-87.

28. Aylaz R, Işsk K, Bayır B, Yetiş G. Üriner inkontinansın 65 yaş ve üzeri kadınların yaşam kalitesi üzerine etkisi. İnönü Üniversitesi Sağlık Bilimleri Dergisi 2016;5:19-25.

29. Yu Ko, Lin SC, Salmon JW, Bron MS. The Impact of Urinary Incontinence on quality of life of the elderly. Am J Manag Care 2005;11:103-11.

30. Özkan ZS, Sapmaz E. Prevalence and risk factors of female urinary incontinence during the reproductive stage. Scie 2014;25:101-6.

31. Hunskaar S, Vinsnes A. The quality of life in women with urinary incontinence as measured by the sickness impact profile. J Am Geriatr Soc 1991;39:378-82. [CrossRef]

32. Demir G, Erbesler ZA. Quality of life and factors associated with it in elderly women with urinary incontinence. Turkish Journal of Geriatrics 2017;20:213-22.

33. Kocak I, Okyay P, Dundar M, Erol H, Beser E. Female urinary incontinence in the west of Turkey: prevalance, risk factors and impact of quality of life. Eur Urol 2005;48:634-41. [CrossRef]

34. Aslan G, Köseoğlu H, Sadık Ö, Gimen S, Cihan A, Esen A. Sexual function in women with urinary incontinence. Int J Impot Res 2005;17:248-51. [CrossRef]

\section{İnmede Üriner İnkontinansın Yaşam Kalitesi ve Fonksiyonel Duruma Etkisinde Cinsiyetin Rolü}

Amaç: Bu çalışma inmeli hastalarda görülen üriner inkontinansın (Üi) yaşam kalitesi ve fiziksel fonksiyona etkisinde cinsiyetin rolünü belirlemek amacıyla yapılan tanımlayıcı bir çalışmadır.

Gereç ve Yöntem: Haziran-Ağustos 2018 tarihleri arasında bir kamu fizik tedavi ve rehabilitasyon hastanesinde yatan ve polikliniğe başvuran, inme ve Üi tanısı almış 64'ü kadın, 64'ü erkek olmak üzere toplam 128 hasta ile yapıldı. Veriler yapılandırılmış soru formu, SF-36 yaşam kalitesi ölçeği ve Barthel İndeksi ile toplandı.

Bulgular: Çalışmada yer alan hastaların yaş ortalaması, kadın $62 \pm 15.33$, erkek $58.77 \pm 16.10$ yıl idi. Üi sıklığı, kaçırılan idrar miktarı, idrar kaçırma durumunda ne kullanıldığı ve Üi nedeniyle bir sağık kurumuna başvurmada cinsiyetlere göre anlamlı bir fark bulunmazken ( $p>0.05$ ) hastaların ped kullanma durumları ile yaşam kalitesi arasında istatistiksel olarak anlamlı fark saptandı $(p<0.05)$. Üi ve ilgili bazı özelliklere göre SF-36 Yaşam Kalitesi Ölçeği alt boyutlarından alınan puanlara bakıldığında; Üi sıklığına göre olguların SF-36 Yaşam Kalitesi Ölçeği "Fiziksel Sağlık" ve "Mental Sağlık"alt boyutundan aldıkları puanlar arasında istatistiksel olarak anlamlı farklılık saptandı $(p<0.05)$.

Sonuç: Bu çalışmada Üi'nin inmeli hastanın yaşam kalitesini etkilemesinde cinsiyetin rolü olup olmadığı araştırılmış ve Üi'nin cinsiyetten bağımsız olarak hastaların yaşam kalitesini, fiziksel, sosyal, ev, iş ve aile yaşantısını olumsuz yönde etkilediği belirlenmiştir.

Anahtar Sözcükler: Barthel indeksi; cinsiyet; inkontinas; inme; SF36. 